\title{
Comparison between enzyme-linked immunosorbent assay and Immunochromatographic test for the detection of the anti-HCV antibody in Faisalabad
}

\author{
Qurat ul Ain ${ }^{1}$, Ashiq Ali ${ }^{2}$, Nishat Zafar ${ }^{3 *}$, Shaina Akbar ${ }^{4}$, Sadia Yousaf ${ }^{2}$, \\ Tehreem Rana ${ }^{2}$, Amna Shakoor ${ }^{2}$, Muhammad Kashif ${ }^{2}$, Fadia Waheed ${ }^{5}$, \\ Sidra Aslam ${ }^{5}$, Umar Amin ${ }^{6}$, Husnain Idrees ${ }^{2}$ and Muhammad Usman ${ }^{7}$ \\ 1. Department of Microbiology, Government College University Faisalabad (38000) Pakistan \\ 2. Department of Pathology, University of Agriculture, Faisalabad (38000) Pakistan \\ 3. Institute of Microbiology, University of Agriculture, Faisalabad (38000) Pakistan \\ 4. Aziz Fatima Dental and Medical College, Faisalabad (38000) Pakistan \\ 5. Institute of Microbiology and Molecular Genetics, Punjab University Lahore, Pakistan \\ 6. Institute of Physiology, Pharmacy and Pharmacology, University of Agriculture, Faisalabad (38000) Pakistan \\ 7. Department of Botany, University of Agriculture, Faisalabad, Pakistan \\ *Corresponding author's email: nishat_zafar@yahoo.com
}

Citation

Qurat ul Ain, Ashiq Ali, Nishat Zafar, Shaina Akbar, Sadia Yousaf, Tehreem Rana, Amna Shakoor, Muhammad Kashif, Fadia Waheed, Sidra Aslam, Umar Amin, Husnain Idrees and Muhammad Usman. Comparison between enzyme-linked immunosorbent assay and Immunochromatographic test for the detection of the anti-HCV antibody in Faisalabad. Pure and Applied Biology. Vol. 11, Issue 2, pp439-445. http://dx.doi.org/10.19045/bspab.2022.110043

\begin{tabular}{llll}
\hline \hline Received: 01/04/2021 & Revised: 16/07/2021 & Accepted: 28/07/2021 & Online First: 26/08/2021 \\
\hline \hline
\end{tabular}

\section{Abstract}

Hepatitis $\mathrm{C}$ virus is the major cause of chronic liver diseases, cirrhosis, and liver cancer in developed countries. Different factors responsible for hepatitis for example blood transfusion sexual transmission, use of unsterilized syringes. A total of 243 samples were collected from different areas of Faisalabad. Two techniques ICT and ELISA were applied to all samples. After sample processing results of both techniques were compared to check the efficacy of ICT. From 243 samples that are applied to Immunochromatographic technique. A total of 29 samples were positive of $\mathrm{HCV}$ infection. Remaining 214 samples were tested on ELISA than more 23 persons positive for anti HCV antigen. In this study, according to ICT the high prevalence of HCV was found in Lyallpur Town (12.8\%), Iqbal Town (11.6\%), Jinnah Town (14\%), and Madina Town (9.5\%) respectively. According to ELISA prevalence of $\mathrm{HCV}$ is $13.1 \%, 11.6 \%, 11.6 \%, 7 \%$ in Lyallpur Town, Iqbal Town, Jinnah Town, and Madina Town, respectively. According to our result, ELISA is more effective than ICT. Statistical analysis of the data thus obtained was performed using chi chart square.

Keywords: Hepatitis; HCV; Antibody; ICT; ELISA 


\section{Introduction}

Hepatitis C Virus (HCV) is the principal cause of severe liver disease, including hepatocellular carcinoma and cirrhosisrelated disease [1]. Chronic hepatitis C may lead to cirrhosis without the development of significant symptoms. Before the development of liver failure, there may be little to distinguish a person with early or slowly progressive liver disease from a person with progressive liver disease. If Hepatitis $\mathrm{C}$ is present, in the early stage of disease it will show nonspecific symptoms and it is a slowly progressive disease. Some common symptoms of hepatitis $\mathrm{C}$ lead to lethargy, anorexia, nausea, abdominal discomfort, intolerance to alcohol, and fatty foods [2].

The threat to the prevalence of HCV is higher in those patients that are on hemodialysis and hemophilia [3]. Based on epidemiological studies it is proved that HCV is common in Pakistan, but very little data is available on it. There are different types of risk factors that are responsible for the spreading of $\mathrm{HCV}$ infection, especially in developing countries. $\mathrm{HCV}$ infection increased because there are no implementations of international rules that are related to reuse of syringes, blood transfusion, ear piercing, unsterilized syringes or any equipment, etc. Hepatitis C virus can be identified in blood and blood products. This shows that HCV is spread by both types of transmission either by horizontal transmission or vertical transmission. These are two routes by which HCV is spread [4].

In HCV chronic patients, the Level of ALT (alanine aminotransferase) level is high than the normal value. This value confirmed that the positivity of $\mathrm{HCV}$ infection, but ALT level cannot be enough to assess the exact screening of $\mathrm{HCV}$ infection. In the chronic stage of $\mathrm{HCV}$, it has been described that results from viremia showed that $\mathrm{HCV}$ infections may occur at the chronic stage at a rate of $0.50-0.74 \%$ per person [5]. Antibodies of $\mathrm{HCV}$ infection appeared within 3-12 weeks at a measurable level, but the virus of $\mathrm{HCV}$ has been detected in the patient of blood after 1 to 3 weeks [6]. For the detection of anti-HCV antibody or the presence of another virus for example HAV or HBV, Proper diagnosis of anti HCV must be done for evaluating the anti-HCV antibody. Estimation of the Anti-HCV level does not notify the correct stage of infection such as acute, prolonged, or fixed infection. A supplement test should also perform to verify the positive anti-HCV result [7]. Treatment of $\mathrm{HCV}$ infection has been declared by interferon-based treatment in 1989. No vaccine has been introduced against the dangerous pathogen even in nowadays. By antiviral treatment, a good percentage of people get rid of or $\mathrm{HCV}$ infection if $\mathrm{HCV}$ is treated in the early stage. HCV infection can be cured completely and treated by early medical treatment, but in the early stage of $\mathrm{HCV}$ infection, it does not be detected infected individual or mild symptoms have appeared. The course of antiviral therapy contained ribavirin and pegylated interferon. This therapy shows good results. About 42 to $82 \%$ of people show no response that has chronic HCV infection $[8,9]$. The laboratory diagnosis of $\mathrm{HCV}$ infection is usually made based on the detection of circulating antibodies. Serological tests for detecting antibodies to HCV are generally classified as a screening test or confirmatory test. Screening tests provide the presumptive identification of antibodies in specimens, whilst the confirmatory test is used to confirm that specimens found reactive with a particular screening test contain antibodies specific to HCV. Several screening tests may be used in testing to determine the final serostatus. Simple instrument and electricityfree screening tests have been developed including agglutination, immune filtration (flow-through), and 
immunochromatographic (lateral flow) membrane tests. The immunochromatographic test is rapid and simple and could be used along with rapid determination, in settings with limited facilities [10]. Faisalabad is one of the largest cities in Pakistan and this city prevalence of Hepatitis $\mathrm{C}$ is increasing day by day. The present study was designed to analyze the effectiveness of testing kits for screening for $\mathrm{HCV}$ and to compare the effectiveness of ELISA and ICT for the screening of HCV.

\section{Materials and Methods}

\section{Sample size}

Blood samples $(n=243)$ were collected randomly from the general population in about three months. The sample size was calculated by keeping in consideration the expected prevalence at $20 \%$ with a $95 \%$ confidence level and a desired absolute precision of 5\% to take the maximum number of samples [11, 12]. The calculation of the sample size was done with the help of following formula:

$\mathrm{n}=1.96^{2} \operatorname{Pexp}(1-\mathrm{Pexp}) / \mathrm{d}^{2}$

\section{Sample collection}

A total of $3 \mathrm{ml}$ venous blood was aseptically collected in gel \& clot activator tubes (Improvacuter ${ }^{\circledR}$, China) and left to clot for a half-hour at- $4^{\circ} \mathrm{C}$. An identification code was given to each sample. The samples were then shifted to Post Graduate Laboratory, Department of G.C University Faisalabad in Microbiology department.

\section{Immunochromatographic technique}

The HCV Ab Rapid Test Cassette (serum) is a flow chromatographic immunoassay for the qualitative detection of antibodies ( $\mathrm{IgG}, \mathrm{IgM}$, and $\mathrm{IgA}$ ) anti-Hepatitis $\mathrm{C}$ virus (HCV) in human serum. All the serum samples were subjected to Immunochromatographic techniques as described by the manufacturer [13].

\section{Procedure}

Before starting the procedures specimen and all reagents were kept to room temperature.
The test strip was detached from the foil pouch and kept on a clean dry surface. $5 \mu 1$ serum sample was dropped on the sample pad and two drops of buffer were dispenced to it. The results were after 15 minutes according to the formation of the color band. To ensure the validity of the kit control was also performed.

\section{Enzyme-linked immunosorbent assay} (ELISA)

The RecombiLISA HCV IgG by CTK (BIOTECH, USA) was used to check the anti HCV antibodies This test is a solid-phase ELISA for the qualitative detection of IgG to Hepatitis C virus (HCV) in human serum or plasma. It is based on the principle of indirect EIA technique for the detection of the IgG to $\mathrm{HCV}$ in human serum or plasma, providing Relative Sensitivity 100\%, Relative Specificity 100\% (Asia et al., 2009).

Results

Immunochromatographic assay

Initially, HCV Ab Detection Rapid Test Cassette was used for the detection of HCV antibodies from patient serum. Briefly, after the addition of serum, the appearance of two colored lines indicated positive cases, whereas the appearance of one color line in the control region indicated negative results. Positive

Both purplish-red test band and purplish-red control formed on the membrane surface.

Negative

Only the purplish red control band formed on the membrane surface and no formation of a band of samples are formed.

\section{ELISA}

ICT positive samples were subjected to ELISA. The RecombiELISA HCV kit specifically quantifies the levels of $\operatorname{IgG}$ antibodies from the serum. The serum samples were processed according to the manufacturer protocol provided along with the kit. The absorbance of the samples was measured at wavelength; the cut-off value was estimated according to the formula. 


\section{Positive}

Absorbance values of specimen equal to or more than the cut-off value (1.00) was measured Anti HCV positive (reactive).

\section{Negative}

Absorbance values of specimen less than the cut-off value were measured Anti-HCV negative (nonreactive).

According to (Table 1), there were a total of 243 samples of HCV suspected patients. The test of ICT was conducted to confirm the presence of $\mathrm{HCV}$ in different patients. After the completion of the ICT test, 29 samples among 243 samples were showed positive results. While 214 samples among 243 samples were showed negative results.

According to (Table 2), there were a total of 214 samples of HCV suspected patients. The ELISA test was conducted to confirm the presence of $\mathrm{HCV}$ in different patients. After the completion of the ELISA test showed, 23 samples among 214 samples were positive results. While 191 samples among 214 samples were showed negative results.
According to (Table 3) total of 243 samples of $\mathrm{HCV}$ suspected patients were collected from the different areas of Faisalabad. 50 samples were collected from Jinnah town, 60 samples were collected from Iqbal town, 70 samples were collected from Lyallpur town and 63 samples were collected from Madina town. ICT tests showed the different percentages of positive results $07(14 \%)$, $07(11.6 \%), 09(12.8 \%)$, and $06(9.5 \%)$ in HCV patients of different towns of Faisalabad respectively.

According to (Table 4) total of 214 samples of HCV suspected patients were collected from the different areas of Faisalabad. 43 samples were collected from Jinnah town, 53 samples were collected from Iqbal town, 61 samples were collected from Lyallpur town and 57 samples were collected from Madina town. ELISA test showed the different percentages of positive results $05(11.6 \%)$, 06(11.6\%), 08(13.1\%), and 04(7\%) in HCV patients of different towns of Faisalabad respectively.

Table 1. Positive and negative samples according to ICT

\begin{tabular}{|l|l|l|}
\hline Total samples & Positive & Negative \\
\hline 243 & 29 & 214 \\
\hline
\end{tabular}

Table 2. Positive and negative samples according to ELISA

\begin{tabular}{|l|l|l|}
\hline Total samples & Positive & Negative \\
\hline 214 & 23 & 191 \\
\hline
\end{tabular}

Table 3. Prevalence of HCV according to ICT

\begin{tabular}{|l|l|l|}
\hline Town & Total samples & Positive samples \\
\hline Jinnah & 50 & $07(14 \%)$ \\
\hline Iqbal & 60 & $07(11.6 \%)$ \\
\hline Lyallpur & 70 & $09(12.8 \%)$ \\
\hline Madina & 63 & $06(9.5 \%)$ \\
\hline
\end{tabular}

Table 4. Prevalence of HCV according to ELISA

\begin{tabular}{|l|l|l|}
\hline Town & Total samples & Positive samples \\
\hline Jinah & 43 & $05(11.6 \%)$ \\
\hline Iqbal & 53 & $06(11.6 \%)$ \\
\hline Lyalpor & 61 & $08(13.1 \%)$ \\
\hline Madina & 57 & $04(7 \%)$ \\
\hline
\end{tabular}




\section{Comparison of ICT and ELISA}

According to our result, the prevalence of HCV was found $12.8 \%, 11.6 \%, 14 \%, 9.5 \%$ in Lyallpur Town, Iqbal Town, Jinnah Town, and Madina Town respectively by the use of ICT. However, with the use of ELISA, the prevalence of $\mathrm{HCV}$ was $13.1 \%, 11.6 \%$, $11.6 \%$ and $7 \%$ in Lyallpur Town, Iqbal Town, Jinnah Town, and Madina Town respectively. According to our study highly occurrence of $\mathrm{HCV}$ was present according to ELISA in Lyallpur Town in and in ICT Jinnah Town by both techniques.

\section{Discussion}

Globally hepatitis $\mathrm{C}$ virus has become a great health problem for many decades. HCV infections have a significant role in causing inflammation of hepatic cells, chronic hepatitis, and being leading causes of cirrhosis and hepatocellular carcinoma and finally deaths. It is a major public health issue worldwide, especially in developing countries like Pakistan. In chronic hepatitis $\mathrm{C}$, people often progress to cirrhosis without the development of significant symptoms. Before the development of liver failure, there may be little to distinguish a person with early or slowly progressive liver disease from a person with progressive liver disease. A total number of 243 blood samples were collected from healthy individuals aseptically in the decided population. All the samples were collected in gel clot vials. Than centrifuged at $5000 \mathrm{rpm}$ for 5 minutes to separate sera and shifted to serum tubes and stored at $-4^{0} \mathrm{C}$ for further processing. The screening was done by Enzyme-Linked Immunosorbent Assay (ELISA) by following standard procedure and manufacturer guidelines, and Immunochromatographic techniques to evaluate the efficacy of ICT.

After performing ELISA and ICT, all the data obtained were tabulated in an excel spreadsheet. A Chi-square test was performed. According to our study high prevalence of $\mathrm{HCV}$ was found in Jinnah
Town (12.8\%)) by ICT. In other Towns, Town, Iqbal Town, Jinnah Town, and Madina Town $11.6 \%$, 14\%, $9.5 \%$ respectively. According to ELISA high prevalence of $\mathrm{HCV}$ was found in Lyallpur Town (13.1\%). In other Towns, Iqbal Town, Jinnah Town and Madina11.6\%, 11.6\%, and $7 \%$ respectively.

For the detection of anti $-\mathrm{HCV}$ antibodies, the findings of the present study were accordant to the reports Ahmad et al. [14] who documented (20.6\%) seropositivity against HCV infection in healthy blood donors visiting Allied Hospital Faisalabad. Muhammad et al. [15] reported the HCV prevalence in District Buner was $4.5 \%$. While Ahmad et al. [16] investigated the seroprevalence of HCV was $13.8 \%$ in Sawat District. In contrast, Arshad et al. [17] investigated the $(3.66 \%) \mathrm{HCV}$ prevalence in the general targeted population of District Mardan which is actually at a lower level than our findings. District are much aware of the factors which cause $\mathrm{HCV}$ infection, there may be a good sanitation system in that area or general population may not have as much hospital visits as a population of Faisalabad have.

In a recent study number of positive patients' samples in ICT is increased than the ELISA this might be due to the false-positive result that is given by Immunochromatographic technique.

Ullah et al. [18] investigated also supported the error chances in the ICT technique This result agreed with the previous study of Ewis et al., [19]. They investigated that total samples were 2000. 177 were positive for anti HCV with ICT and more 77 samples were positive on ELISA which means it gives false positive. This study was conducted in Jinnah medical college Lahore. Overall, $2.35 \%$ of samples show false positive. Erhabor et al. [20] also investigated the competency of ELISA in Usman Danfodiyo University Teaching Hospital Sokoto, North- 
Western Nigeria. Khan et al. [21] also have a predominance of $\mathrm{HCV}$ prevalence in males than female participants in Lakki. By previous study and our study, it is concluded that ELISA is more effective than ICT.

Arshad et al., (2012) documented that 41-50 years of the population was more prone to this infection by screening anti HCV antibodies. Secondary infections are the leading reasons for this age group that made people more vulnerable to this deadly infection. According to this study, it is estimated that operated volunteers are more prone to HCV infection. Transfusion of blood has been a foremost cause of $\mathrm{HCV}$ transmission; however, owing to the transmission through transfusions and improved screening, the transmission has diminished in most developed countries. Yet, the rate of transfusion-related hepatitis $\mathrm{C}$ is still greater in other areas of the world that make people more inclined to get this infection.

\section{Conclusion}

An epidemiological study should be done on a large scale to evaluate the $\mathrm{HCV}$ prevalence at a wide spectrum. There is also a need for molecular characterization to determine the most prevalent HCV genotype in the area of Faisalabad, and consequently genotypespecific anti-viral therapies should be introduced to minimize the burden of $\mathrm{HCV}$ infection. It is very important to make policies and standards to improve our diagnostic level and reduced the risk factors that are responsible for $\mathrm{HCV}$ infection.

\section{Authors' contributions}

Conceived and designed the experiments: Q Ain, Performed the experiments: N Zafar \& A Ali, Analyzed the data: S Akbar, S Yousaf, T Rana \& A Shakoor, Contributed materials/ analysis/ tools: F Waheed, H Idrees \& M Usman, Wrote the paper: S Aslam, U Amin, N Zafar \& A Ali.

\section{References}

1. Zia R, Afridi IUK, Rafiq H, Sheikh GA
\& Abbas F (2016). Magnitude of Hepatitis C Virus Infection among Asymptomatic Pakistani children. Pak J of Med \& Health Sci 10(3): 902-904.

2. Lawitz E, Sulkowski MS, Ghalib R, Rodriguez-Torres M, Younossi ZM, Corregidor A \& Lim JK (2014). Simeprevir plus sofosbuvir, with or without ribavirin, to treat chronic infection with hepatitis $\mathrm{C}$ virus genotype 1 in non-responders to pegylated interferon and ribavirin and treatmentnaive patients: the COSMOS randomised study. The Lancet 384(9956): 1756-1765.

3. Umar M, and Bilal M. (2012). Hepatitis C, a mega menace: A Pakistani perspective. J of Pak Med Stud 2(2): 6872.

4. Shah FU, Salih M, Malik IA, and Hussain I. (2002). Increasing prevalence of chronic hepatitis and associated risk factors. Pak J of Med Res 41(2): 46-50.

5. Patel J, and Sharma P. (2020). Design of a novel rapid immunoassay for simultaneous detection of hepatitis $\mathrm{C}$ virus core antigen and antibodies. Arch of Virol 165(3): 627-641.

6. World Health Organization. Hepatitis C. Available at: www.who.int/vaccine research / viral cancers. Retrieved on 1604-2009.

7. Strader DB, Wright T, Thomas DL, and Seeff LB. (2004). Diagnosis, management, and treatment of hepatitis C. Hepatol 39(4): 1147-1171.

8. Manns MP, McHutchison JG, Gordon SC, Rustgi VK, Shiffman M, Reindollar $\mathrm{R} \quad \& \quad$ International Hepatitis Interventional Therapy Group (2001). Peginterferon alfa- $2 b$ plus ribavirin compared with interferon alfa-2b plus ribavirin for initial treatment of chronic hepatitis C: a randomised trial. The Lancet 358(9286): 958-965.

9. Fried MW, Shiffman ML, Reddy KR, Smith C, Marinos G, Gonçales Jr FL \& 
Craxi A (2002). Peginterferon alfa-2a plus ribavirin for chronic hepatitis $\mathrm{C}$ virus infection. New Eng J of Med 347(13): 975-982.

10. Niamatullah N (2020). Comparative analysis of $\mathrm{HCV}$ through ICT and ELISA, A contributing factor of $\mathrm{HCV}$ infection in district Killa-Saifullah, Balochistan. European Acad Res J 8(1).

11. Nafees M, Bhatti MS, and Haq IU. (2007). Sero-prevalence of HCV Antibodies in population attending Madina Teaching hospital, Faisalabad. Annals of King Edward Med Uni 13(4): 260-260.

12. Lwanga SK, Lemeshow S \& World Health Organization. (1991). Sample size determination in health studies: a practical manual. World Health Organization.

13. Arca-Lafuente S, Martínez-Román P, Mate-Cano I, Madrid R \& Briz V (2020). Nanotechnology: A reality for diagnosis of HCV infectious disease. $J$ of Infect 80(1): 8-15.

14. Ahmad N, Asgher M, Shafique M, and Qureshi JA. (2007). An evidence of high prevalence of Hepatitis C virus in Faisalabad, Pakistan. Saudi Med J 28(3): 390.

15. Muhammad N \& Jan MA (2005). Frequency of hepatitis $\mathrm{C}$ in Buner, NWFP. J of the Coll of Phys and Surgeons-Pak 15(1): 11-14.
16. Ahmad A, Ahmad B, Ali A \& Ahmad Y (2009). Seroprevalence of HBsAg and anti-HCV in general healthy population of Swat district with frequency of different HCV Genotypes. Pak J Med Sci 25(5): 744-748.

17. Arshad A, Arshad M, Pervaiz R, Farzana JA \& Ahmad ND (2012). Prevalence of active Hepatitis-C infection in the general Population of District Mardan, Khyber Pakhtunkhwa. Pak J of Pub Health Biol Sci 1(1): 3-8.

18. Ullah A, Rehman IU, Ahmad J, Gohar M, Ahmad S \& Ahmad B (2020). HepatitisC Virus and Cirrhosis: An Overview from Khyber Pakhtunkhwa Province of Pakistan. Viral Immunol.

19. Ewis AA, Khalil DM, Arafa AE, Salam ZMA, Elhefny MA \& El-Badawy A. (2020). Validation of a rapid screening diagnostic test kit for field investigations of hepatitis $\mathrm{C}$ viral infection.

20. Erhabor O, Kwaifa I, Bayawa A, Isaac Z, Dorcas I \& Sani I. (2014). Comparison of ELISA and rapid screening techniques for the detection of HBsAg among blood donors in Usmanu Danfodiyo university teaching hospital Sokoto, North Western Nigeria. J of Blood and Lymph 4(2): 124.

21. Khan MI \& Muhammad M (2012). Frequency of Hepatitis B and C in Patients Visiting Outpatient Department of District Head Quarters Hospital Lakki. $J$ of Post Med Inst 26(1). 